\title{
Accounting standards for small and medium-sized entities Evidence from Spain
}

\section{Patricia Milanés \\ Montero \\ Universidad de Extremadura pmilanes@unex.es}

Irene Albarrán Lozano Universidad de Extremadura ialbaloz@unex.es

Joaquín Texeira Quirós Universidad de Extremadura jtexeira@unex.es

Esteban Pérez Calderón Universidad de Extremadura estperez@unex.es

\begin{abstract}
By approving Regulation 1606/2002, the European Commission entrusts the local European Union regulators with the difficult decision as to whether making the International Accounting Standards (IAS/IFRS) extensive for their Small and Medium-sized Entities or not. International Financial Reporting Standard for Small and Medium-sized Entities (hereinafter IFRS for SMEs) was published in 2009, and the European Commission had also decided to seek the opinion of EU stakeholders on this Standard. We understand that the European accounting regulators' position should be based on the analysis of the extent to which current domestic standards allow useful financial information to be provided by and to these companies. Therefore, this paper presents empirical evidence regarding Spanish SMEs' characteristics, timely facing the harmonization process, in order to determine if the information provided according to the national standards accomplishes the required usefulness. Its purpose is to share facts and data about this kind of still underestimated companies, though of great economic and social significance in Spain and in Europe in general.
\end{abstract}

Keywords: SMEs, financial information, usefulness, accounting harmonization 


\section{Normas contables para pequeñas y medianas empresas. Evidencia para España}

\section{Resumen}

Con la aprobación del Reglamento 1606/2002, la Comisión Europea dejó en manos de los reguladores europeos la difícil tarea de decidir entre exigir o no a sus pequeñas empresas la aplicación de las normas internacionales de contabilidad (NIC/NIIF). La IFRS for Private Entities elaborada por el IASB fue publicada en 2009 y ya ha sido sometida a la opinión de los stakeholders de la Unión por parte de la Comisión Europea. Ante esta situación la posición por adoptar al respecto por los reguladores comunitarios debería basarse en el análisis del grado de utilidad de la información financiera elaborada por sus Pyme con la información doméstica actual. Es por ello que este trabajo ofrece evidencia empírica en relación con las características de las Pyme frente al proceso armonizador con la intención de determinar si la información proporcionada con la normativa nacional permite dar cumplimiento al objetivo de utilidad. El propósito perseguido es aportar luz acerca de este tipo de entidades aún muy desconocidas a pesar de su gran importancia económica y social en España y en toda Europa.

Palabras clave: Pyme, información financiera, utilidad, armonización contable.

\section{Introduction}

Regulation 1606/2002, approved by the European Commission (EC) on June $7^{\text {th }}$ 2002, gave all Member States the power to decide which accounting standards apply to individual annual accounts of companies. This means that every European Union (EU) country has to evaluate the most appropriate position regarding their individual companies and non-listed groups within regulated markets. Among these are the Small and Medium-Sized Enterprises (SME), highly recognized for their contribution to wealth and employment. However, in spite of their significant economic and social role, SMEs have never received the attention they deserve, namely under the accounting point of view (EC, 2002).

Under this reasoning, even in 1999 the advantage of making use of change to improve the financial information provided by the SMEs stood out, highlighting the improvement of financial states' usefulness regarding management decisions (Moneva et al., 1999; Serra, 2002).

So far, the Spanish position regulated in the new Plan General de Contabilidad para Pequeñas y medianas empresas aproved by the ICAC- Instituto de Conta- 
bilidad y Auditoría de Cuentas- in 2008) is that the accounting standards used by SMEs would be as similar as possible to the International Accounting Standards. On the other hand, the International Financial Reporting Standards (IFRS) for Small and Medium-Sized Entities are derived from full IFRSs with appropriate modifications based on the needs of users of private entity financial statements and cost-benefit considerations (IASB, 2009). This standard coul be adopted by the EC and, owing to it, the European regulators would have to decide whether to extend this IASB standard for smaller entities to their own SMEs (IASB, 2004).

In our opinion, any European regulators' position should be based on an analysis of whether their current accounts meet their utilitarian purpose. According to the Conceptual Structures Theory, this purpose is shaped by the environment in which the entity carries out its activity, concretely by its users. According to several authors, these are mainly SMEs managers and financial institutions (Moneva, 1999; Carsberg et al., 1985; Paolini and Demartini, 1997). Therefore, one of the main purposes that SMEs annual reports should accomplish is to provide useful information for managers to make management decisions.

Notwithstanding, in order to understand whether the SMEs' current annual reports do accomplish this purpose, we need to have a deeper knowledge of the users' information needs. The only way to do it is to analyze users' behaviour through inductive studies. However, due to the scarcity of this kind of studies, authors are restrictes to making assumptions (Gabás y Bellostas, 2000). In order to mark out the type of information and, therefore, the international accounting standards that Member States should apply to their SMEs, we have to have a deeper knowledge of the specific characteristics of these companies and of the usefulness level granted to the information they provide according to their current domestic accounting standards.

Labrador (1998) analyzes the usefulness that the annual information provided by a sample of non-publicly traded medium-sized enterprises to its users-both internal (managers) and external (creditors, clients and competitors) and he concludes that, in all cases, their own information is seen as less useful. On the other hand, Moneva et al. (2001) analyze the impact of the financial information to European SMEs, specifically in Italy and Spain. Results show that the usefulness perception of financial information differs in these countries: whereas Italian managers find that information quite useful to influence management decisions, Spanish managers find it as a last resource. 
Therefore, the purpose of this paper is to identify the distinctive features of Spanish SMEs and which of these determine the usefulness perceptions of their managers regarding their own financial reports.

The Spanish Experts Commission itself was conscious of the fact that the application of the international accounting standards may be of great difficulty for small enterprises, especially for new entrants. Therefore, the Commission found it essential to define their distinctive features as soon as possible, and a similar position was that of the United Nation's ad hoc consultative group of experts on small and medium-sized enterprises' accounting of the Intergovernmental Working Group of Experts on International Standards of Accounting and Reporting (ISAR). Nevertheless, the standard proposed by the IASB to be used by smaller entities defines them as entities that do not have public accountability and report general purpose financial statements for external users.

So, in order to meet our purposes, we begin with an overview of published literature related to the classification of smaller Spanish entities. Specifically, as a starting point to ground our study, we review the existing legal definitions of SMEs and the efforts made by several authors in order to measure enterprises' size. Subsequently, we present the research methodology used in this paper and, finally, we comment on the main results and conclusions in relation with the characteristics of Spanish SMEs, financial information's usefulness and economization, and the causes of the breach in usefulness purposes in SMEs'accounting.

\section{Overview of accounting and non-accounting literature on different sized en- terprises}

Both European ${ }^{1}$ and Spanish ${ }^{2}$ law use quantitative criteria to classify SMEs by size (annual income, number of employees and total asset), which may cause some disadvantages (Moneva, 1993): instability ${ }^{3}$; lack of comparability (comparisons between SMEs are not possible because these criteria were set up regardless of the applicable industry and geographical area); arbitrariness; uncertainty (that can

${ }^{1}$ Council Directive 78/660/ECC, Official Journal of the European Union, L 224/1, 16.8.2006

${ }^{2}$ Plan General de Contabilidad (Real Decreto 1514/2007) and Plan General de Contabilidad de PYMEs (Real Decreto 1515/2007) approved by the ICAC.

${ }^{3}$ This lack of stability is proved by the five revisions made up to the time this article was written. Moreover, they were affected by the changes in the measure unit, which is no longer a problem since the euro was adopted as the single european monetary unit. 
affect calculations on their relative significance); problems associated to the use of number of employees ${ }^{4}$ and the inconsistency of some criteria.

So, in our proposal of SMEs' definition, besides using quantitative criteria, we will also use qualitative variables that allow us to identify different sized enterprises' categories, regarding several aspects related to their accounting activity, to the usefulness granted to this activity in order to obtain management information, their directive structure, the complexity of their decision processes, etc.

In relation with the more commonly used criteria on previous studies about SME's definition, throughout history, the more accepted qualitative criteria are the following three with eight definitions for each of them: coincidence between property and management (Kaplan, 1948; Moneva, 1993; Salas, 2003); reduced significance in the sector or scarce participation in the market share (Moneva, 1993; Salas, 2003); independence in property and direction in respect to other entities' policies (Moneva, 1993; Salas, 2003).

Personalized management is the next more common criterion and it is based on four definitions. Hollander (1967), Rojo et al. (1983), Salas (2003) and Moneva (1993) gather in their definition proposal the three more common criteria after analyzing the existing qualitative definitions and, in addition, they include the nonexistence qualitative criterion of a completely developed administrative entity.

Aspects related to the infringement of functional purposes of the SMEs' accounting and the causes of this infringement can also be seen as characteristics or distinctive qualitative criteria of SMEs in accounting scope and, therefore, we specify them: scarce or non-existent usefulness of the provided annual accounts to their management decisions ${ }^{5}$; ignorance of the strategic value of the financial information; considering the accounting a cost and not an investment ${ }^{6}$; Scarce accounting instruction; decisions based on quantitative data obtained from unofficial accounting and according to their intuition and experience as managers.

\footnotetext{
${ }^{4}$ Invalidation for such external causes as the restrictions to the freedom of admissions and discharging that derives from certain legislations can be an inconvenience. In spite of such inconvenience, this is the most commonly used criterion in a multitude of definitions, maybe because it is easy to get information on the subject. ${ }^{5}$ Especially in those companies that let external advisers elaborate their accounts, which represent $80 \%$ of the ones analyzed

${ }^{6}$ Remember that, according to this study's results, this cause (attributable to the manager) is the main reason why the financial problems exist in the analyzed enterprises
} 
The more commonly used quantitative criterion among the diverse theoretical definitions of SME is the average number of employees, which has twenty followers, as shows Table 1.

Table 1

Quantitative criteria used to define SMEs

\begin{tabular}{|c|c|c|}
\hline $\begin{array}{l}\text { Quantitative } \\
\text { criteria }\end{array}$ & Definitions & Sources \\
\hline nTotal assets & $\begin{array}{l}\text { Total assets in the year } \\
\mathrm{n}-1 \text { plus total assets in } \\
\text { year } \mathrm{n} \text {, divided by two. }\end{array}$ & $\begin{array}{l}\text { IV Directive of Company Laws (1978); Proposal of } \\
\text { Directive CEE (1988); } \text { ASC }^{7} \text { (1988 b); TRLSA (1989); } \\
\text { PGC (1990); Moneva (1993); Recommendation 96/280/ } \\
\text { CE; Recommendation 2003/361/CE }\end{array}$ \\
\hline Revenue & Number of businesses & $\begin{array}{l}\text { IV Directive of Company Laws }(1978)^{8} \text {; SSAP } \mathrm{n}^{\circ} 15 \\
\text { del ASC (1975); Ley de la Reforma Mercantil (1989); } \\
\text { APD } \text { (1977); Bolton Report CSIF (1971); Proposal of } \\
\text { Directive CEE (1988); ASC (1988 b); TRLSA (1989); } \\
\text { PGC (1990); Moneva (1993); Ministery of Industry and } \\
\text { Energy (Orden de 8/5/1995); Recommendation 96/280/ } \\
\text { CE; Recommendation 2003/361/CE }\end{array}$ \\
\hline $\begin{array}{l}\text { Number of } \\
\text { employees }\end{array}$ & $\begin{array}{l}\text { Number of employees } \\
\text { in the year n-1 plus } \\
\text { number of employees } \\
\text { in the year n, divided } \\
\text { by two. }\end{array}$ & $\begin{array}{l}\text { IV Directive of Company Laws (1978); SSAP n }{ }^{\circ} 15 \\
\text { del ASC (1975); APD (1977); IMPI }{ }^{10} \text { (1983); European } \\
\text { Investments Bank; Bolton Report CSIF (1971); } \\
\text { Selective Service Act (1948); Small Business Act } \\
\text { (1953); Proposal of Directive CEE (1988); ASC (1988); } \\
\text { TRLSA (1989); PGC (1990); Moneva (1993); Mutual } \\
\text { Guarantee companies Law (1/1994 de 11/03/1994); } \\
\text { Ministery of Industry and Energy (Orden de 8/5/1995); } \\
\text { Recommendation 96/280/CE; Inform of the UNCTAD } \\
\text { Secretary (2000); Recommendation 2003/361/CE }\end{array}$ \\
\hline Equity & $\begin{array}{l}\text { It includes the financial } \\
\text { resources in the firm } \\
\text { that aren't going to be } \\
\text { required. }\end{array}$ & APD (1977) \\
\hline $\begin{array}{c}\text { Net } \\
\text { inmovilized }\end{array}$ & $\begin{array}{l}\text { Inmovilized less } \\
\text { depreciation and } \\
\text { provisions. }\end{array}$ & European Investments Bank \\
\hline
\end{tabular}

${ }^{7}$ Accounting Standards Committee.

${ }^{8}$ Statement of Standard Accounting Practice.

${ }^{9}$ Association for management progress.

${ }^{10}$ Spanish Industrial SMEs Institute. 


\section{Continuación table 1}

\begin{tabular}{|c|c|c|}
\hline $\begin{array}{l}\text { Quantitative } \\
\text { criteria }\end{array}$ & Definitions & Sources \\
\hline $\begin{array}{l}\% \text { capital / } \\
\text { shareholder }\end{array}$ & $\begin{array}{l}\text { Percentage of capital } \\
\text { controlled by a single } \\
\text { shareholder }\end{array}$ & European Investments Bank \\
\hline $\begin{array}{c}\text { Number of } \\
\text { vehicles }\end{array}$ & $\begin{array}{l}\text { Average number of } \\
\text { vehicles }\end{array}$ & Bolton Report CSIF (1971) \\
\hline $\begin{array}{l}\text { Number of } \\
\text { branches }\end{array}$ & $\begin{array}{l}\text { Average number of } \\
\text { branches }\end{array}$ & Bolton Report CSIF (1971) \\
\hline Independence & $\begin{array}{c}\text { Property and } \\
\text { management are not } \\
\text { dependent on the outside }\end{array}$ & $\begin{array}{c}\text { Ministery of Industry and Enery (Orden de } 8 / 5 / 1995 \text { ); } \\
\text { Recomendation 96/280/CE }\end{array}$ \\
\hline
\end{tabular}

Source: Moneva Abadía (1993), Laffarga Briones (1999), IV Directive of Company Laws (1978), TRLSA (1989), PGC (1990), Recommendation 96/280/CE about the definition of SME, Inform of the UNCTAD Secretary (20/04/2000) about the accounting of SMEs, Recommendation 2003/361/ CE which modified the Recommendation 96/280/CE, and self development.

According to Laffarga (1999), in many occasions this indicator has to be used, since there is no other general available information of different activity sectors. Also, Moneva (1993) tries to explain the large acceptation of this criterion by exposing its characteristics as a controllable variable, hardly to be distorted. However, both authors agree with Maroto (1993) on this criterion's limitations, such as restrictions in the liberty of admission and the sector where the company is set. Regarding this last restriction, there are large companies in advanced technological sectors that have a reduced number of workers, while some keep all the characteristics of small companies, but have a high number of employees - this usually happens in the artisan industry.

Following "number of employees" the second more common criterion is the "number of businesses", which has thirteen followers.

Most of the mentioned criteria, along with other quantitative indicators such as obtained benefits, cash-flow, added value ${ }^{11}$, capital ${ }^{12}$, etc, have been used in many empirical investigations to obtain a measure of enterprise size. However, almost

\footnotetext{
${ }^{11}$ Quantitative criterion that Jara (2000) introduced among the group of quantitative criteria that refer to monetary aspects. This author, following Moneva, distinguishes this group from the one referring to people.

${ }^{12}$ As Sotelo (1987) mentions, this criterion is used in some European countries, such as Ireland and Italy.
} 
all of them delimit size for purposes different from the one we pursue in this paper, such as the gap in the existing relations between dimension and growth, dimension and yield, dimension and innovation or dimension and fiscal pressure. Some of them, more in our line, try to detect the possible relation between the size and the quality of the information published in the annual accounts or the spreading level of this information.

Table 2

Empirical studies about the use of quantitative criteria to measure size

\begin{tabular}{|c|c|c|c|c|c|}
\hline $\begin{array}{c}\text { Author } \\
\text { and data }\end{array}$ & Finality & Scope & Criteria & $\begin{array}{c}\text { Methodo- } \\
\text { logy }\end{array}$ & Conclusions \\
\hline $\begin{array}{l}\text { Bueno et al. } \\
\quad \text { (1979) }\end{array}$ & $\begin{array}{c}\text { Find a } \\
\text { multicriteria } \\
\text { value to define } \\
\text { the size }\end{array}$ & $\begin{array}{l}300 \text { highest } \\
\text { firms in } 1976\end{array}$ & $\begin{array}{l}\text { Revenue, } \\
\text { equity, } \\
\text { employees, } \\
\text { added value. }\end{array}$ & $\begin{array}{c}\text { Linear } \\
\text { combination } \\
\text { of variables }\end{array}$ & $\begin{array}{l}\text { Starting point } \\
\text { to investigate } \\
\text { this topic }\end{array}$ \\
\hline $\begin{array}{l}\text { Bueno et al. } \\
\quad \text { (1981) }\end{array}$ & $\begin{array}{c}\text { Find the best } \\
\text { methodology } \\
\text { to define the } \\
\text { size }\end{array}$ & $\begin{array}{c}250 \text { highest } \\
\text { Spanish private } \\
\text { firms (1978- } \\
79)\end{array}$ & $\begin{array}{l}\text { Revenue, } \\
\text { equity, } \\
\text { employees, } \\
\text { added value, } \\
\text { net profits, } \\
\text { dividends. }\end{array}$ & $\begin{array}{l}\text { Factorial } \\
\text { Analysis }\end{array}$ & $\begin{array}{l}\text { Identification } \\
\text { of Revenue, } \\
\text { employees and } \\
\text { equity as the } \\
\text { best variables } \\
\text { to measure } \\
\text { size }\end{array}$ \\
\hline $\begin{array}{c}\text { Bueno \& } \\
\text { Lamothe } \\
\text { (1986) }\end{array}$ & $\begin{array}{l}\text { Analysis } \\
\text { of size- } \\
\text { rentability } \\
\text { relation }\end{array}$ & $\begin{array}{c}250 \text { highest } \\
\text { Spanish private } \\
\text { firms (1979- } \\
82)\end{array}$ & $\begin{array}{l}\text { Revenue, } \\
\text { equity, } \\
\text { employees, } \\
\text { net profits, } \\
\text { dividends, } \\
\text { cash-flow }\end{array}$ & $\begin{array}{l}\text { Factorial } \\
\text { Analysis }\end{array}$ & $\begin{array}{l}\text { Identification } \\
\text { of Revenue, } \\
\text { employees and } \\
\text { equity as the } \\
\text { best variables } \\
\text { to measure size }\end{array}$ \\
\hline $\begin{array}{l}\text { Barbadillo } \\
\text { et al. } \\
\text { (2002) }\end{array}$ & $\begin{array}{l}\text { Analysis of } \\
\text { size-quality } \\
\text { relation of } \\
\text { accounting } \\
\text { information }\end{array}$ & $\begin{array}{c}1.194 \\
\text { Spanish listed } \\
\text { companies. } \\
\text { Bolsa de } \\
\text { Madrid (1991- } \\
\text { 96) }\end{array}$ & Total Assets & $\begin{array}{l}\text { Division } \\
\text { of sample } \\
\text { into size } \\
\text { quartiles }\end{array}$ & $\begin{array}{l}\text { Identification } \\
\text { of four size } \\
\text { categories of a } \\
\text { similar number } \\
\text { of firms }\end{array}$ \\
\hline $\begin{array}{c}\text { Correa et } \\
\text { al. } \\
(2002)\end{array}$ & $\begin{array}{l}\text { Analysis of the } \\
\text { relation size- } \\
\text { growth }\end{array}$ & $\begin{array}{c}1.092 \text { no- } \\
\text { financial } \\
\text { Canarian firms } \\
\text { (small, sevices } \\
\text { sector) } \\
(1990-96)\end{array}$ & $\begin{array}{l}\text { Total assets, } \\
\text { equity, } \\
\text { revenue, } \\
\text { added value. }\end{array}$ & $\begin{array}{c}\text { Factorial } \\
\text { and cluster } \\
\text { analysis }\end{array}$ & $\begin{array}{c}\text { Identification } \\
\text { of five size } \\
\text { categories } \\
\text { (micro, small, } \\
\text { medium, big, } \\
\text { very big), } \\
\text { measured with } \\
\text { the variables: } \\
\text { total assets, } \\
\text { equity, revenue } \\
\text { and added } \\
\text { value }\end{array}$ \\
\hline
\end{tabular}

Source: Author's Elaboration 


\section{Continuación table 2}

\begin{tabular}{c|c|c|c|c|c}
\hline $\begin{array}{c}\text { Author } \\
\text { and data }\end{array}$ & Finality & Scope & Criteria & $\begin{array}{c}\text { Methodo- } \\
\text { logy }\end{array}$ & Conclusions \\
\hline $\begin{array}{c}\text { Calvé } \text { et al. } \\
(2005)\end{array}$ & $\begin{array}{c}\text { Analysis of } \\
\text { size- } \\
\text { Tax burden } \\
\text { relation after } \\
\text { the approval } \\
\text { of the Spanish } \\
\text { Law } 43 / 1995 \\
\text { of Corporate } \\
\text { tax }\end{array}$ & $\begin{array}{c}60.364 \\
\text { Valencian } \\
\text { small firms } \\
\text { according to } \\
\text { art. } 122 \text { of the } \\
\text { Law } 43 / 95\end{array}$ & Revenue & $\begin{array}{c}\text { Division } \\
\text { of sample } \\
\text { into size } \\
\text { quartiles }\end{array}$ & $\begin{array}{c}\text { There is a } \\
\text { direct relation } \\
\text { between tax } \\
\text { burden and } \\
\text { size }\end{array}$ \\
\hline $\begin{array}{c}\text { Milanés } \\
(2007)\end{array}$ & $\begin{array}{c}\text { Proposal } \\
\text { of a SME } \\
\text { definition for } \\
\text { accounting } \\
\text { purposes }\end{array}$ & $\begin{array}{c}\text { Spanish firms } \\
(2001)\end{array}$ & $\begin{array}{c}\text { Several } \\
\text { cualitative } \\
\text { and } \\
\text { quantitative } \\
\text { criteria }\end{array}$ & $\begin{array}{c}\text { Analysis and } \\
\text { Logit }\end{array}$ & $\begin{array}{c}\text { Definition of } \\
\text { two categories } \\
\text { of SMEs } \\
\text { based on } \\
\text { cualitative and } \\
\text { quantitative } \\
\text { criteria }\end{array}$ \\
\hline
\end{tabular}

Only three of these studies have included the small company scope. These are the ones by González y Correa (1998), González et al. (2000) and Rodriguez et al. (2001) for the Canarian community, whose enterprise structure is characterized precisely by its reduced dimension. In these three, the multivariate statistical techniques used were factorial analysis and cluster analysis.

The multicriterion value obtained as a measure of the enterprise dimension contains, in all of them, the following variables: assets, profits of exploration and added value. The study of González et al. (2000) also includes the equity variations. As far as the categories of SMEs identified with the cluster analysis are concerned, González y Correa (1998) distinguish four, of which only two - medium and small - could be SMEs, since the other two are too big. Correa et al. (2002) states that there are five groups and another category of SME, the microcompany.

However, according to the results of the three analyses, we highlight the inverse relation between the number of companies of each identified groups and their dimension, which confirms just what González et al. (2000) pointed out: the sample slanting towards small dimension companies is most of all a reflection of both the Canarian and the national economy.

Concerning the investigations that, just like in our line of work, try to relate dimension with level of spreading or quality of the accounting information, Rivero $y$ 
Ochoa (2002) agree that in all studies about information's quality there is proof of a positive relation between the spreading level and the size of the company, due to aspects such as a higher capacity to cut on the information costs, access to capitals market, higher pressure from the state organisms and the investors and lesser competitive disadvantage than the small companies. However, as already confirmed, neither previous authors nor Barbadillo et al. (2002) apply statistical techniques that demonstrate the size levels of the analyzed companies.

Zorio (2001) emphasizes, as shown in previous sections, that the company's size is decisive to fill international standards requirements. Thus, it is easier for larger companies rather than small ones to adopt these standards, since their competitive disadvantages and information costs are relatively smaller. Although the measure of size used by the author suffers from multiple imperfections and is poorly representative of real enterprise dimension in the EU, her work is of great contribution towards the present European harmonization process and the imminent reformation of members' accounting systems and it shows the difficulty in adopting a positioning regarding small size companies. In this sense, our proposal tries to clarify, as far as possible, the adaptation process of this complex decision to the Spanish state.

\section{International definition: ISAR, IASB, EFRAG.}

As we summarize in Table 3, ISAR's Special Consultative Group proposes a generic and guiding definition of SMEs, letting each State member that decides to apply it to establish more specific criteria such as number of businesses, number of workers and total assets. In fact, it is not possible to establish the limits between the three levels of companies identified by the Consultative Group without knowing the concrete economy in which they act. It is necessary to take into account the economic, legal and social circumstances of each country, as well as its enterprise structure.

The ISAR remarks that the lack of a universal definition of SMEs is due to the existing differences in such circumstances and insists on the need of having a definition, at least at a national scope, with the purpose of undoubtedly identifying the group of companies that are destined to use the accounting standards and to, therefore, facilitate their fulfilment. 
On the other hand, the IASB defines the term "small and medium-sized entities" in the context of the IFRS for SMEs as entities that do not have public accountability and publish general purpose financial statements. So, this definition is therefore based on the nature of an entity rather than on its size.

In relation with it, in 2008, EFRAG recommends the IASB not to revert to one of its earlier ideas and re-label the standard as -IFRS for NPAE's- (non publicly accountable entities). The label needed to be more user-friendly, easy to translate and to use positive expressions.

Table 3

\section{ISAR's definition for accounting effects}

\begin{tabular}{|c|c|c|c|}
\hline $\begin{array}{c}\text { Company } \\
\text { levels }\end{array}$ & \multicolumn{2}{|c|}{ Characteristics } & $\begin{array}{c}\text { Accounting } \\
\text { system }\end{array}$ \\
\hline Level I & \multicolumn{2}{|c|}{$\begin{array}{l}\text { * Issue public values or } \\
\text { * Present a great public interest [to be among the first 10\% } \\
\text { of the country's employers] } \\
\text { * Banks and financial establishments }\end{array}$} & $\begin{array}{l}\text { *Complete } \\
\text { fulfilment of the } \\
\text { IFRS }\end{array}$ \\
\hline Level II & \multicolumn{2}{|c|}{$\begin{array}{l}\text { * Companies of a certain commercial organization that do not } \\
\text { issue public values nor financial information to the public in } \\
\text { general. } \\
\text { * They can have shareholders who do not comprise of the direction } \\
\text { of the company [Property \# Management] } \\
\text { * Endowed with their own accounting personnel that is able } \\
\text { to follow the track of the transactions and to watch for the } \\
\text { company's credit situation } \\
\text { * More than a few employees }\end{array}$} & $\begin{array}{l}\text { * Partial } \\
\text { fulfilment of the } \\
\text { IFRS }\end{array}$ \\
\hline \multirow[t]{2}{*}{ Level III } & \multirow{2}{*}{$\begin{array}{l}\text { - Lack of resources } \\
\text { - Simplicity of operations } \\
\text { - Limited knowledge/accounting } \\
\text { infrastructure } \\
\text {-Difficulties to obtain banking } \\
\text { and commercial credits } \\
\text {-Difficulties to obtain reasonable } \\
\text { accounting services }\end{array}$} & $\begin{array}{l}\text { A) Small companies } \\
\text { *Managed by their proprietors } \\
\text { [Property = Management] } \\
\text { *Few workers }\end{array}$ & $\begin{array}{l}* \text { Simple } \\
\text { cumulative } \\
\text { accounting }\end{array}$ \\
\hline & & $\begin{array}{l}\text { B] Companies of recent } \\
\text { creation or that have entered } \\
\text { formal accounting for the } \\
\text { first time }\end{array}$ & $\begin{array}{l}\text { * Cash } \\
\text { accounting } \\
\text { [exceptionally] }\end{array}$ \\
\hline
\end{tabular}

Source: Milanés y Texeira (2006) 


\section{Methodology}

The purpose of our empirical study is to detect small and medium Spanish enterprises' characteristics and to analyze which of these influence the usefulness level they get from the financial information elaborated according to domestic standards all of this will contribute to clarify to what extent the application of international standards to these companies would be appropriate.

Within this purpose, we studied the behaviour of 500 Spanish companies ${ }^{13}$ that, in 2003, fulfil the Fourth Directive's criteria for medium sized companies through an opinion poll. According to Giner (2000), this is the investigation technique used in studies that focus on the Individual User, given the inexistence of structured models that relate information to its specific use by users. Percentage of answers was $22.25 \%{ }^{14}$.

The questionnaire, based on previous literature and directed to the sample's company managers, is divided into three parts: a] in the first, we included questions of organizational type and on the property's structure; b] the second part is composed by questions related to accounting aspects such as the usefulness granted to the accounting information while taking management decisions, the managers' entanglement in the accounting activity, their knowledge of the matter and the economization they impute to informationgiven; d] and the third part includes questions related to these companies' age and to the type of operations they accomplish.

In order to complete the study, we include financial indicators and qualitative variables such as the sector in which the companies develop their activity and the quality of their management. This information was obtained from the ARDÁN's Information Service.

Figures 1 and 2 and 3 show a summary of all these variables analyzed.

\footnotetext{
${ }^{13}$ These companies were selected through a sample stratified by Autonomous Communities and Sector of Activity.

${ }^{14}$ This percentage of answers is quite acceptable, especially if we compare it to those of previous exploratory investigations that have followed the same methodology. Related to this, Muñoz and Cordón (2002), in their study on the size-structure-innovation relation, collected data through a postal poll of national range (to more than 500 workers' companies), obtaining a $18.82 \%$ index of answers. What, according to them, is quite normal in national context (Ortega, 1994).
} 


\section{Figure 1}

\section{Quantitative variables to measure characteristics of SMEs}

\begin{tabular}{l|ll}
\multicolumn{1}{c}{ Aspect } & \multicolumn{1}{c}{ Variable } & \multicolumn{1}{c}{ Value } \\
& a] Assets & $-\leq 1.000 .000 €$ \\
\cline { 2 - 3 } Financial & b] Number of businesses & $->1.000 .000 €$ \\
\hline indicators & & $-\leq 2.000 .000 €$ \\
\cline { 2 - 3 } & \multirow{2}{*}{ c] Number of employees } & $->2.000 .000 €$ \\
\hline
\end{tabular}

Source: Author's elaboration

Figure 2

\section{Qualitative variables to measure characteristics of SMEs}

\begin{tabular}{|c|c|c|c|}
\hline Aspect & Variable & \multicolumn{2}{|c|}{ Value } \\
\hline & a] Customized management & \multicolumn{2}{|c|}{$\begin{array}{l}\text {-Yes } \\
\text {-No }\end{array}$} \\
\hline $\begin{array}{l}\text { 1. Organizational } \\
\text { type and } \\
\text { property's }\end{array}$ & $\begin{array}{l}\text { b] Coincidence of property and } \\
\text { direction }\end{array}$ & \multicolumn{2}{|c|}{$\begin{array}{l}\text {-Total Coincidence } \\
\text {-Partial Coincidence } \\
\text {-No coincidence }\end{array}$} \\
\hline structure & $\begin{array}{l}\text { c] Property and direction } \\
\text { independent of the exterior }\end{array}$ & \multicolumn{2}{|c|}{$\begin{array}{l}\text {-Yes } \\
\text {-No }\end{array}$} \\
\hline $\begin{array}{l}\text { 2. Accounting } \\
\text { type }\end{array}$ & $\begin{array}{l}\text { a] Responsibility in the Accounts' } \\
\text { elaboration and deposit }\end{array}$ & \multicolumn{2}{|c|}{$\begin{array}{l}\text {-Company's own enabled } \\
\text { accountants } \\
\text {-External advisers, through the } \\
\text { company's accounting } \\
\text {-External advisers through the } \\
\text { company's invoices }\end{array}$} \\
\hline & b] Limited accounting knowledge & \multicolumn{2}{|l|}{$\begin{array}{l}\text {-Yes } \\
\text {-No }\end{array}$} \\
\hline & a] Companies' antiquity & \multicolumn{2}{|l|}{$\begin{array}{l}-<3 \text { years } \\
-\geq 3 \text { years }\end{array}$} \\
\hline \multirow{3}{*}{$\begin{array}{l}\text { 3. Other } \\
\text { qualitative } \\
\text { characteristics }\end{array}$} & b] Type of operations & \multicolumn{2}{|l|}{$\begin{array}{l}\text {-In cash } \\
\text {-On credit }\end{array}$} \\
\hline & $\begin{array}{l}\text { c] Sector in which they develop its } \\
\text { activity }\end{array}$ & $\begin{array}{l}\text {-Construction } \\
\text {-Retailers } \\
\text {-Manufacturers } \\
\text { Transportation } \\
\text {-Drivers } \\
\end{array}$ & $\begin{array}{l}\text {-Mining } \\
\text {-Services } \\
\text { - }\end{array}$ \\
\hline & d] Good management indicators & \multicolumn{2}{|c|}{$\begin{array}{l}\text {-Quality certificate -High } \\
\text { performance }\end{array}$} \\
\hline
\end{tabular}

Source: Author's elaboration 


\section{Figure 3}

\section{Qualitative variables to measure the usefulness and the economization of information}

\begin{tabular}{|c|c|c|}
\hline Aspect & Variable & Value \\
\hline \multirow{2}{*}{$\begin{array}{l}\text { 1. Level of usefulness } \\
\text { and economization of } \\
\text { financial inform. }\end{array}$} & $\begin{array}{l}\text { a] Use of financial information } \\
\text { to make management decisions }\end{array}$ & $\begin{array}{ll}\text {-Never } & \text {-Frequently } \\
\text {-Sometimes } & \text { - Always } \\
\text {-Indifferent } & \\
\end{array}$ \\
\hline & b] Information's economization & $\begin{array}{l}\text {-Positive cost- benefit relation } \\
\text {-Negative cost- benefit relation }\end{array}$ \\
\hline $\begin{array}{l}\text { 2. Use of unofficial } \\
\text { accounting } \\
\text { information }\end{array}$ & $\begin{array}{l}\text { a] Use of unofficial accounting } \\
\text { information }\end{array}$ & $\begin{array}{ll}\text {-Never } & \text {-Frequently } \\
\text {-Sometimes } & \text { - Always } \\
\text {-Indifferent } & \end{array}$ \\
\hline $\begin{array}{l}\text { 3. Use of intuition } \\
\text { and experience to take } \\
\text { management decisions }\end{array}$ & $\begin{array}{l}\text { a] Use of intuition and } \\
\text { experience to make } \\
\text { management decisions }\end{array}$ & $\begin{array}{ll}\text {-Never } & \text {-Frequently } \\
\text {-Sometimes } & \text { - Always } \\
\text {-Indifferent } & \end{array}$ \\
\hline
\end{tabular}

Source: Author's elaboration

The empirical study, firstly, analyzes the characteristics of Spanish SMEs that face the International accounting harmonization and the usefulness and economization of financial information. Then, it analyzes the causes of the usefulness purpose breach detected in SMEs' accounting by means of the test of these four hypotheses:

H1: Manager's accounting instruction does not influence the usefulness problems.

H2: The manager's mentality does not influence the usefulness problems.

H3: The main purpose with which managers elaborate Accounts does not influence the usefulness problems.

H4: The manager's implication in the accounting tasks does not influence the usefulness problems.

The statistical techniques applied to data, using the statistics program SPSS version 15.0 were a t-test and an ANOVA. The t-test is a statistical hypothesis test in which the test statistic follows a Student's t distribution if the null hypothesis ( $\mathrm{H} 1$, H2, H3) is supported. The ANOVA F-statistic is a ratio of the Between Group Variation divided by the Within Group Variation which is used to test the null hypothesis $\mathrm{H} 4$. A large $\mathrm{F}$ will be evidence against $\mathrm{H}$, since it indicates that there is more difference between groups than within groups. 


\section{Results obtained}

Characteristics of Spanish SMEs that face the international accounting harmonization

Table 4 shows that in most of our sample's SMEs (in more than 80\%), property and direction are independent of the exterior, just like Moneva (1993) and Salas (2003) defend for smaller dimension companies, and there is a coincidence between property and company's direction, just like the previous authors as Kaplan (1948) point out. Also, more than one person takes part in the management of $79.6 \%$ of the companies.

In addition, these companies do not have good management indicators (only one of them is Gacela, three have high performances and eight have a quality certificate). Almost all of the companies have been in the formal economy for more than three years and display such values of assets, number of businesses and number of employees that do not allow them to adopt the simplified accounting regime regulated by the recent Limited Society New Company's Law, developed and regulated by royal decree. In addition, only $12 \%$ of the companies declare to pursue most of their operations in cash as opposed to $87 \%$ that assure to do it on credit. This makes them very similar to the smaller size companies that were defined by the Secretary of UNCTAD, that pursue many operations on credit [medium], great part of them (small) or not too many (microcompanies).

Peculiarly, only $28.7 \%$ of the interviewed SMEs recognize having limited accounting knowledge, which, as many authors endorse, is one of the main causes of the accounting problematic in the SMEs. Nevertheless, 63\% declare having to resort to external professionals to elaborate their annual accounts. In addition, only $40 \%$ submits these accounts to an audit and possibly they just do it because of legal demand. 
Table 4

\section{Characteristics of those interviewed}

\begin{tabular}{|c|c|c|}
\hline & $\mathrm{F}$ & $\%$ \\
\hline \multicolumn{3}{|l|}{ 1. Organizational type and property's structure } \\
\hline \multicolumn{3}{|l|}{ a] Customized management } \\
\hline Yes & 20 & 19.6 \\
\hline No & 86 & 80.4 \\
\hline TOTAL & 107 & 100 \\
\hline \multicolumn{3}{|l|}{ b] Coincidence of property and direction } \\
\hline Total Coincidence & 62 & 59.8 \\
\hline Partial Coincidence & 28 & 26.2 \\
\hline No coincidence & 15 & 14 \\
\hline TOTAL & 107 & 100 \\
\hline \multicolumn{3}{|l|}{ c] Property and direction independent of the exterior } \\
\hline Yes & 92 & 86 \\
\hline No & 14 & 14 \\
\hline TOTAL & 107 & 100 \\
\hline \multicolumn{3}{|l|}{ 2. Accounting type } \\
\hline \multicolumn{3}{|l|}{ a] Responsibility in the Accounts' elaboration and deposit } \\
\hline Company’s own enabled accountants & 39 & 36.4 \\
\hline External advisers, through the company's accounting & 58 & 54.2 \\
\hline External advisers through the company's invoices & 10 & 9.3 \\
\hline TOTAL & 107 & 100 \\
\hline \multicolumn{3}{|l|}{ b] Limited accounting knowledge } \\
\hline Yes & 31 & 29.9 \\
\hline No & 75 & 70.1 \\
\hline TOTAL & 107 & 100 \\
\hline \multicolumn{3}{|l|}{ 3. Other qualitative characteristics } \\
\hline \multicolumn{3}{|l|}{ a] Companies' age } \\
\hline$<3$ years & 1 & 0.9 \\
\hline$\geq 3$ years & 106 & 99.1 \\
\hline TOTAL & 107 & 100 \\
\hline \multicolumn{3}{|l|}{ b] Type of operations } \\
\hline - $\quad$ In cash & 13 & 12.1 \\
\hline On credit & 94 & 87.9 \\
\hline$-\quad$ TOTAL & 107 & 100 \\
\hline \multicolumn{3}{|l|}{ c] Sector in which they develop its activity } \\
\hline - Construction & 12 & 11 \\
\hline - $\quad$ Retailers & 15 & 14 \\
\hline - $\quad$ Manufacturers & 10 & 9 \\
\hline - $\quad$ Drivers & 14 & 13 \\
\hline - $\quad$ Mining & 1 & 1 \\
\hline - $\quad$ Services & 38 & 36 \\
\hline - $\quad$ Transportation & 17 & 16 \\
\hline - $\quad$ TOTAL & 107 & 100 \\
\hline
\end{tabular}

Source: Author's Elaboration 


\section{Continuación table 4}

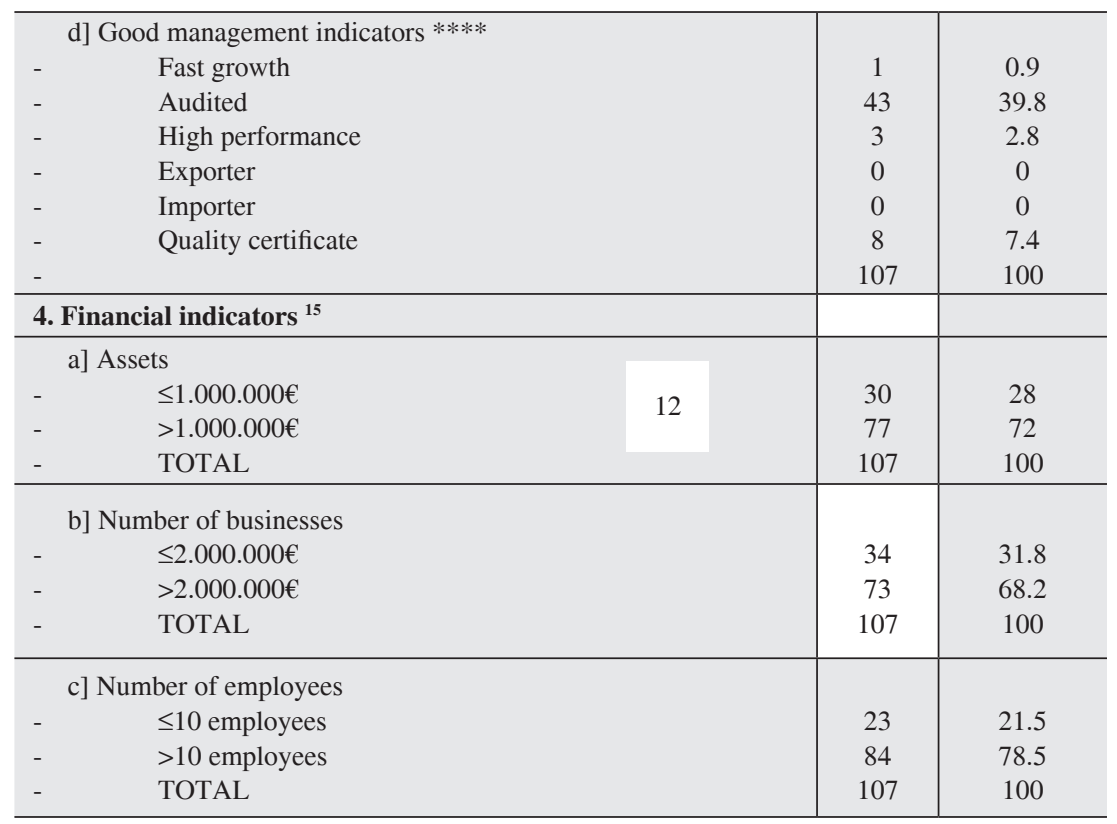

\section{Financial information's usefulness and economization}

The importance of financial information's usefulness and economization is made simple in the IFRS for SME elaborated by the IASB, given that it is derived form full IFRSs with appropriate modifications based on the needs of users of private entity financial statements and cost-benefit considerations.

In connection with it, Castrillo et al. (1998) ascertain that some works, like the ones done at national range by Carmona y Céspedes (1996), have made clear that the information provided by financial accounting is, without a doubt, insufficient to be able to carry out the directors' process of decision making and that most companies elaborate another type of accounting information related to the external movement of values to solve those deficiencies. Although the author does not

\footnotetext{
${ }^{15}$ Maximum limits that companies have to fulfil to adopt the simplified accounting regime due in Law 7/2003 of the Limited Society New Company.
} 
suggest reduced dimension companies in a specific way, he refers to the financial information and the enterprise management that is our purpose here. In addition, he recognizes that the other type of information is in the scope of the so-called directive accounting or accounting for the management and, because of that, questions the relevance of the information provided by the financial accounting.

In fact, as shown in Table 5, the $75 \%$ of the companies of our sample declare not to make regular use of the financial information to take management decisions, although more than $50 \%$ favourably value the cost-benefit relation derived from this information, which points out to the possibility that they consider it useful for other purposes.

Table 5

Valuation granted by managers to financial and non-financial information

\begin{tabular}{|c|c|c|}
\hline \multirow{2}{*}{\multicolumn{3}{|c|}{$\begin{array}{l}\text { 1. Level of usefulness and economization granted to the } \\
\text { elaborated financial information }\end{array}$}} \\
\hline & & \\
\hline $\begin{array}{ll} & \text { a] Use of financial information to take management decisions } \\
- & \text { Never } \\
- & \text { Sometimes } \\
- & \text { Indifferent } \\
- & \text { Frequently } \\
- & \text { Always } \\
\text { TOTAL }\end{array}$ & $\begin{array}{c}52 \\
13 \\
13 \\
5 \\
22 \\
107\end{array}$ & $\begin{array}{c}48.1 \\
12 \\
12 \\
4.6 \\
20.4 \\
99.1\end{array}$ \\
\hline $\begin{array}{l}\text { b] Information's economization } \\
-\quad \text { Positive cost- benefit relation } \\
-\quad \text { Negative cost- benefit relation } \\
\text { - }\end{array}$ & $\begin{array}{c}56 \\
51 \\
107\end{array}$ & $\begin{array}{l}51.9 \\
47.2 \\
99.1\end{array}$ \\
\hline \multicolumn{3}{|l|}{ 2. Use of unofficial accounting information } \\
\hline $\begin{array}{ll}- & \text { Never } \\
- & \text { Sometimes } \\
- & \text { Indifferent } \\
- & \text { Frequently } \\
- & \text { Always } \\
- & \text { TOTAL } \\
\end{array}$ & $\begin{array}{c}61 \\
3 \\
13 \\
17 \\
9 \\
107\end{array}$ & $\begin{array}{c}56.5 \\
2.8 \\
12 \\
15.7 \\
8.3 \\
99.1\end{array}$ \\
\hline \multicolumn{3}{|l|}{ 3. Use of intuition and experience to take management decisions } \\
\hline $\begin{array}{ll}- & \text { Never } \\
- & \text { Sometimes } \\
- & \text { Indifferent } \\
- & \text { Frequently } \\
- & \text { Always } \\
- & \text { TOTAL } \\
\end{array}$ & $\begin{array}{c}11 \\
19 \\
14 \\
41 \\
18 \\
107 \\
\end{array}$ & $\begin{array}{c}10.2 \\
17.6 \\
13 \\
38 \\
16.7 \\
99.1\end{array}$ \\
\hline
\end{tabular}

Source: Author's Elaboration 
One of the direct investigations made in specific countries displayed by the Secretary of the UNCTAD's Report (2000), mentioned above, recognized the fact that certain managers consider several aspects: one on banking and financial effects, another one on the payment of taxes and a third on management. Nevertheless, more than half of the Spanish SMEs of our sample say they do not use this type of information.

However, the data collected through our opinion poll show that intuition and experience are indispensable instruments for more than half of the small Spanish companies' managers at the time of making decisions related to the business progress.

In any case, everything seems to point out to a generalized tendency to consider that the information elaborated within a Spanish small company does not serve the managers' needs for decision making and, therefore, it fails to fulfil one of its main purposes.

\section{Causes of the usefulness purpose breach in SMEs accounting}

In order to verify if a] the accounting instruction of the managers, b] their mentality, c] the purpose with which Annual Accounts are elaborated and d] their higher or lower implication in this task are determining aspects of the usefulness level granted to the accounting information, we contrasted four null hypotheses of equality of the average values that variable Usefulness can adopt for each one of the groups defined by the possible values of the previous variables.

Tables 6 and 7 illustrate that at a 95\% level of confidence the value of the probability associated to the contrast statistical provides evidence against the null hypothesis of averages equality. Therefore, just as Sotelo (1987) pointed out in the 80's decade, the lack of accounting instruction of Spanish SMEs' managers within our sample and their mentality of still considering accounting more as a cost than as an investment, is a significant variable, which means that they favour the breach of the financial information's usefulness purpose.

Concerning both causes attributable to the managers, the Secretary of the UNCTAD's Report (2000) establishes that the accounting advantages in the sense that it provides a model that allows the company to improve its yield and management are not normally appraised (perhaps by the manager's lack of instruction in terms of management), or are not properly.appraised. 
It is logical to think that, as a result of these causes attributable to the small manager and the ones previously mentioned, regulation responsibility and profession within our country, the proprietors dedicate a minimum part of their time and resources to the elaboration of the Annual Accounts, restraining to fulfil their accounting obligations with the only purpose of avoiding sanctions by breach.

Table 6

Influence of the manager's accounting instruction on the usefulness problems H1

\begin{tabular}{l|r|r|r|r|r}
\hline \multirow{2}{*}{ Usefulness } & \multicolumn{2}{|c|}{$\begin{array}{c}\text { Levene's test for } \\
\text { variances' equality }\end{array}$} & \multicolumn{3}{c}{ T test for averages' equality } \\
\cline { 2 - 6 } & $\mathrm{F}$ & Sig. & $\mathrm{T}$ & \multicolumn{1}{c|}{$\mathrm{gl}$} & \multicolumn{1}{c}{ Sig. [bilateral] } \\
\hline $\begin{array}{l}\text { Equal variances have been } \\
\text { assumed }\end{array}$ & & & & & .062 \\
$\begin{array}{l}\text { Equal variances have not been } \\
\text { assumed }\end{array}$ & 20.504 & .000 & -1.884 & 102 & .036 \\
\hline
\end{tabular}

Table 7

Influence of the manager's mentality on the usefulness problems (H2)

\begin{tabular}{l|c|c|c|c|c}
\hline \multirow{2}{*}{ Usefulness } & \multicolumn{2}{|c|}{$\begin{array}{c}\text { Levene's test for } \\
\text { variances' equality }\end{array}$} & \multicolumn{3}{|c}{ T test for averages' equality } \\
\cline { 2 - 6 } & $\mathrm{F}$ & Sig. & \multicolumn{1}{c}{$\mathrm{T}$} & $\mathrm{gl}$ & \multicolumn{1}{c}{ Sig. [bilateral] } \\
\hline $\begin{array}{l}\text { Equal variances have been } \\
\text { assumed }\end{array}$ & 23.290 & .000 & -2.321 & 103 & .022 \\
$\begin{array}{l}\text { Equal variances have not } \\
\text { been assumed }\end{array}$ & & & -2.339 & 98.667 & .021 \\
\hline
\end{tabular}

Nevertheless, as we can see in Tables 8 and 9, neither the fact that the SMEs' managers elaborate Accounts solely to fulfil legal obligation nor their higher or lower implication in elaborating these Accounts are determinant aspects of these problems.

In spite of this, Del Brio (1995) establishes that in our country's small and medium enterprises the elaboration of accounting information is not more valuable than the one that only fulfils legal obligations (Annual Accounts deposit in the corresponding Commercial Registry or tax liquidation's display before Public Property). Therefore, scarce human and material resources are assigned to this function. In this sense, Zamora (1998) shows how the accounting information that is provided to Public Property is the only reason why there is Accounting in the immense majority of the small and medium companies and, in spite of this, it is not even useful to them since they are so aggregate and scarce. 


\section{Table 8}

Influence of the main purpose with which managers elaborate Accounts on the usefulness (H3)

\begin{tabular}{l|c|c|c|c|c}
\hline \multirow{2}{*}{ Usefulness } & \multicolumn{2}{|c|}{$\begin{array}{c}\text { Levene's test for } \\
\text { variances' equality }\end{array}$} & \multicolumn{3}{c}{ T test for averages' equality } \\
\cline { 2 - 6 } & $\mathrm{F}$ & Sig. & \multicolumn{1}{c|}{$\mathrm{T}$} & \multicolumn{1}{c|}{$\mathrm{gl}$} & \multicolumn{1}{c}{ Sig. [bilateral] } \\
\hline $\begin{array}{l}\text { Equal variances have been } \\
\text { assumed }\end{array}$ & & & & & \\
$\begin{array}{l}\text { Equal variances have not } \\
\text { been assumed }\end{array}$ & 1.348 & .258 & -.668 & 23 & .511 \\
\hline
\end{tabular}

Table 9

Influence of the manager's implication in the accounting tasks on usefulness (ANOVA) (H4)

\begin{tabular}{l|l|c|l|l|c}
\hline Usefulness & Squares'sum & $\mathrm{gl}$ & Quadratic average & $\mathrm{F}$ & Sig. \\
\hline Intercompanies & .359 & 2 & .179 & & \\
Intracompanies & 19.698 & 102 & .193 & .929 & .398 \\
Total & 20.057 & 104 & & & \\
\hline
\end{tabular}

In any case, the results are only valid for the sample of SME being analyzed, although they could guide the Spanish regulator (ICAC) in the current period of accounting reform. Their main implication is to demonstrate the great problem of usefulness existing in Spanish SMEs and to find their causes. Therefore, the need to encourage accounting training for businessmen is obvious and to change their mind in order to make them capable of representing SME.

\section{Conclusions and recommendations}

The accounting regulation should be the minimum possible to guarantee its purposes and to not generate undue costs that could invalidate their fulfilment or, what is worse, the own enterprise activity (Martínez, 1998).

We favour such a need of normalization without which information would require certain qualitative characteristics derived from the already mentioned relevance and reliability basic requisites, such as comparability and objectivity and, therefore, the fulfilment of its objective would not be guaranteed. Nevertheless, we understand that rules on their own, if inadequate, can be the causes of failure. 
In relation to this and pointing out to empirical evidence on the subject, we showed in this article the proximity between the information provided by Spanish SMEs according to their domestic accounting standards and its purpose. In addition, after verifying that this information does not help the manager to make management decisions, we have analyzed the possible causes of this problematic. And it all has been carried out with the purpose of showing the situation of Spanish SMEs at the moment and the problems they are having while facing the European harmonization process.

We understand that if in the domestic scope the standards made for large companies are not appropriate for the small ones, because it obstructs the fulfilment of their accounting usefulness purposes, it is very unlikely that the unique standard demanded by the EC in Regulation 1606/2002 concerning large quoted groups would be appropriate for these smaller entities. On the other hand, International Financial Reporting Standard for Small and Medium-sized Entities, elaborated by the IASB and published in 2009, derive from full IFRSs whit appropriate modifications based on the needs of users of private entity financial statements and cost-benefit considerations.

Owing to the fact that EC could adopt this "IFRS for SME's", we recommend that each Country Member's regulator remember the financial information's usefulness and comparability purposes at the time of deciding whether to extend full IFRSs or IFRS for smaller entities of IASB to their SMEs and define the present situation of these companies as the starting point of the reformation they decide to take later. In fact, after approval of IFRS for SMEs, the EC decided to seek the opinion of EU stakeholders on this Standard, and divergent opinions were expressed with regard to the potential application of the IFRS for SMEs in Europe. There were also calls for the EU to take the lead in the international harmonization efforts by adopting the IFRS for SMEs.

As far as the Spanish case is concerned, the empirical evidence displayed in this article shows the need to work in the causes of this problematic that are attributable to the own manager, fomenting its instruction on accounting matters and improving his accounting conception, and to analyze the information needs of SMEs' managers before valuing the suitability of the international accounting standards for them. 
This is our main recommendation which is directly addressed to the Spanish accounting regulator (ICAC) but can serve as reference for other regulators of EU member countries and even the EC. Apart from that, we also recommend:

- That the existing relation between the issues legislated by the international regulation and the real activity of smaller companies should be analyzed in all the member States. This analysis could even be done jointly with the countries of similar economic backgrounds. We think that the ISAR guidelines serve as a good reference for this purpose.

- That this analysis should be done taking into account the informative needs of the companies analyzed as well as the economic viability of the regulations evaluated. These issues are basic elements for the conceptual framework that, in our opinion, would increase the reliability of any proposal suggested for this purpose.

In short, we consider the need to begin a discussion about SMEs within the EU a very important one. In such a discussion, the possible consequences of the IFRS application for private entities to the European SMEs should be noticed.

However, due to the limitations of this study derived from the analyzed data and statistical techniques used, we propose as future research:

- To expand the sample of Spanish companies and the period analyzed in order to extrapolate the results to the population. To repeat the study in other European Union countries for the establishment of comparisons among them for the purpose of guiding/in order to guide the European Commission in the adoption of an objective decision about the extent of IFRS for SMEs to European SME.

- To expand this analysis to the Portuguese SME because there is no doubt that many benefits would be derived from the existence of a joint accounting regulatory framework for Spanish and Portuguese SMEs. 


\section{References}

Barbadillo Ruíz, E., N. Gómez Aguilar y A. Guiral Contreras (2002). Una comparación intersectorial y por tamaño de la calidad de la información contable a través del análisis del informe de auditoría. Revista Española de Financiación y Contabilidad. 31(112): 545-581.

Bueno Campos, E., I. Cruz Roche, J. J. Durán Herrera (1979). Economía de la empresa. Análisis de las decisiones empresariales. Madrid: Pirámide.

Bueno, E. y P. Lamothe (1986). Tamaño y rentabilidad de la gran empresa española: un análisis empírico de su relación basado en un método multicriterio. II Congreso de la Asociación Española de Contabilidad y Administración de Empresas (AECA), Madrid.

Bueno, E., P. Lamothe, D. Villalba (1981). Un método multicriterio para medir el tamaño: aplicación a la gran empresa española. Cuadernos universitarios de planificación empresarial CUPE 7(3-4): 731-752.

Calvé Pérez, J. I., G. Labatut Serer y R. Molina Llopis (2005). Variables económico-financieras que inciden sobre la presión fiscal soportada por las empresas de reducida dimensión: efectos de la reforma fiscal de 1995 en las empresas de la comunidad Valenciana. Revista Española de Financiación y Contabilidad, 34(127): 875-897.

Carmona, S. y J. Céspedes (1996). Información contable externa y posición competitiva. Madrid: Instituto de Contabilidad y Auditoría de Cuentas.

Carsberg, B., M. Page, A. Sindall and I. Waring (1985). Small company financial reporting. London: Prentice-Hall Internacional.

Castrillo Lara, L., S. San Martín Gutiérrez, C. de Pablo Ándres, B. Prieto Moreno (1998). La información contable en el ámbito de los sistemas de dirección. VI Congreso de Economía Regional de Castilla y León (Zamora). Libro de comunicaciones II: 1161-1180.

Correa Rodríguez, A., A. L. González Pérez y M. Acosta Molina (2002). Crecimiento y Pyme: un estudio empírico. Revista Europea de Dirección y Economía de la Empresa 3: 76-102. 
Del Brio González, E. (1995). El sistema de información contable. Actualidad Financiera 42: 1143-1159.

European Commission, EC (2002): Regulation European Communities (EC) $n^{\circ}$ $1606 / 2002$ of the European parliament and of the council of 19 July 2002 on the application of IAS, Brussels.

Gabás, F. y A. Bellostas (2000). El marco conceptual para la información financiera. Análisis y comentarios. Madrid: AECA.

Giner Inchausti, B. (2000). Marco conceptual e investigación empírica. Madrid: AECA.

International Accounting Standards Board, IASB (2004). Preliminary views on accounting standards for small and medium-sized entities. Discussion Paper, June. IASB, London.

(2009). IFRS for small and medium-sized entities. www.ifrs.org Fecha de consulta: 27 de julio de 2009.

Jara Sarrúa, L.A. (2000). Una introducción al concepto de pequeña y mediana empresa (Pyme). Trabajo publicado en el portal docente de la Universidad de Zaragoza, España. Disponible en: http://www.ciberconta.unizar.es/LECCIÓN/pyme1. Fecha de consulta: 6 de octubre de 2004.

Kaplan, A. (1948). Small business, its place and problems. New York: McGrawHill.

Labrador Barrafón, M. (1998). ¿Es útil la información contable en la mediana empresa? Efectos de PGC de 1990. Partida Doble, 90end_of_the_skype_highlighting: 58-67.

Laffarga Briones, J. (1999). El análisis económico-financiero de las pequeñas y medianas empresas. V Jornadas de Trabajo sobre análisis contable. Cádiz: Asociación Española de Profesores Universitarios de Contabilidad (ASEPUC). 
Maroto Acín, J.A. (1993). La situación económico-financiera de las empresas españolas y la competitividad. Aspectos generales y particulares de la financiación de las Pyme, Economía Industrial 291: 89-106.

Martínez Gómez, F. (1998). Competitividad: formación, simplificación, fiscalidad. Iniciativa Pyme de Desarrollo Empresarial, 771, 31-39.

Milanés Montero, P. (2007). Propuesta de una definición de Pyme con fines contables. Técnica contable, 59(654): 31-39.

Milanés Montero, P., J. Texeira Quirós (2006). Valoración de la idoneidad de la normativa internacional contable para las Pyme españolas. Revista de contabilidad y tributación: comentarios, casos prácticos, 276, 211-262.

Moneva Abadía, J. M. (1993). El marco de la información contable de Pymes. ICAC, Madrid.

, M. Paolini y P. Demartini (1999). Contabilidad para la Pyme en la Unión Europea: análisis de la utilidad para la gestión. X Congreso de la AECA, Zaragoza.

(2001). El impacto de la información financiera para la Pyme en la Unión Europea: el caso de Italia y España. Técnica contable, 53(626), 131144.

Muñoz Fernández, M.A. and E. Cordón Pozo (2002). Tamaño, estructura e innovación organizacional. Revista Europea de Dirección y Economía de la Empresa, 11(3): 103-120.

Ortega, M. (1994). "La central de balances del banco de España. Una fuente de información sobre las empresas no financieras españolas". Economía Industrial, septiembre-octubre: 121-135.

Paolini M. and P. Demartini(1997). Small company financial reporting: users and information needs. In Evans L. and di Pietra R., 2005, Comment on the IASB discussion paper: Preliminary views on accounting standards for small and medium-sized entities, 24p. 
Rivero Fernández, M. D. y E. Ochoa Laburu (2002). Nivel de divulgación de la información financiera de las empresas gallegas y guipuzcuanas como respuesta de la adaptación de la legislación mercantil española a las directivas comunitarias -un estudio empírico. Revista de contabilidade y comercio 229: 88-119.

Rodríguez A., I. Idígoras, J. Matey (2001). Pymes excelentes. El caso del país Vasco. Papeles de economía española 89-90: 386-401.

Rojo, M., P. Lamothe, E. Moreau (1983). Financiación de la pequeña y mediana empresa. Servicios de publicaciones de la CAI-APC, Zaragoza.

Salas Ríos, M. (2003). La auditoría en las pequeñas y medianas empresas. Revista técnica 21: 16-21.

Serra Salvador, V, (2002). Las Pymes y las obligaciones contables ante la reforma. Partida doble 136: 70-77.

Sotelo Navalporto, J. (1987). Importancia de las Pymes en la economía española. Situación 3: 5-25.

United Nations Conference on Trade and Development, UNCTAD (2000). Report of the Intergovernmental Working Group of Experts on International Standards of Accounting and Reporting On Its 19th Session. September, Ginebra.<smiles></smiles> 
